\title{
Phenotypic and Genotypic Resistance Profile of Salmonella Typhimurium to Antimicrobials Commonly Used in Poultry
}

http://dx.doi.org/10.1590/1516-635x160293-96

-Author(s)
Biffi CP'
Stefani LM",,II
Miletti LC"
Matiello CA'
Backes RG'
Almeida JM'
Neves GB'
| Graduate Student, Animal Science Gradua-
te School, Universidade do Estado de Santa
de Catarina, CAV, Lages/SC.
" Professor, Animal Science Graduate School,
Universidade do Estado de Santa de Catari-
na, CAV, Lages/SC.
"I Professor, Animal Science Undergraduate
School, Universidade do Estado de Santa
Catarina, CEO, Chapecó/SC.
'v Undergraduate Student, Veterinary Medi-
cine, Universidade do Estado de Santa de
Catarina, CAV, Lages/SC.

- Mail Adress

Corresponding author e-mail address:

Prof. PhD Lenita Moura Stefani

Departamento de Zootecnia, Centro de Educação do Ensino Superior (CEO)

Universidade do Estado de Santa Catarina (UDESC)

Rua Beloni Trombeta Zanin, 68E Bairro Santo Antônio - Chapecó, SC CEP 89815-630

Cel: (49) 9113-1214

Email: borrucia@hotmail.com

\section{nKeywords}

Antimicrobial, gene, resistance, Salmonella.

\begin{abstract}
Isolates of Salmonella sp (104) from poultry samples were isolated and serotyped where eleven were identified as Salmonella Typhimurium (ST). ST isolates were phenotypically tested by disk diffusion and minimum inhibitory concentration (MIC). Four genes related to enrofloxacin (GyrA, GyrB, ParC and ParE), two to gentamicin (AadA and $A a d B$ ) and two to ceftiofur (BlaCMY-2 and AmpC) resistance were searched by PCR. Our results showed ST resistance to all three antibiotics tested $(18.1 \%$ for ceftiofur, $45.4 \%$ for gentamicin, and $18.1 \%$ for enrofloxacin) according to the diffusion test. In the MIC test, the ST isolates showed higher levels of resistance (27.2\% for ceftiofur, $54.5 \%$ for gentamicin, and $18.2 \%$ for enrofloxacin). Three resistance genes out of four searched genes for enrofloxacin were found in the ST isolates. Regarding gentamicin and ceftiofur, resistance genes were found mainly in samples with resistant phenotypic profile. Interestingly, some phenotypically-resistant strains did not present the resistance gene, which suggests an alternative route of resistance. Also, sensitive strains had the presence of the gene. It is possible to conclude that the ST isolates evaluated in this study have a multidrug resistance profile to the antibiotics routinely used in poultry production, and potential of greater levels of resistance in the near future.
\end{abstract}

\section{INTRODUCTION}

Salmonellosis is considered a common cause of foodborne illnesses in humans, representing a significant public health problem in many countries. Studies show that poultry products have been recognized as a major transmitter of these bacteria, taking an important role in disease control (Carrasco et al., 2012).

Due to the increasing incidence of infections by Salmonella sp and frequent reports of multiresistant strains, it is necessary to investigate the mechanisms of resistance used by this microorganism. According to Guerra et al. (2000), the spread of genes that confer resistance to microorganisms is due to the indiscriminate use of antibiotics in veterinary medicine. Those authors found that $31 \%$ of the isolates tested were resistant to all antimicrobials tested, and the species with the highest resistance was $S$. Typhimurium.

The main objective of this study was to investigate the genotypic and phenotypic antimicrobial resistance profile to gentamicin, ceftiofur and enrofloxacin of $S$. Typhimurium of poultry origin.

\section{MATERIALS AND METHODS \\ Isolation}

Salmonella sp isolates (104 samples) of poultry origin from Brazil were obtained from a private and accredited laboratory. These isolates 
Biffi CP, Stefani LM, Miletti LC, Matiello CA, Backes RG, Almeida JM, Neves GB
Phenotypic and Genotypic Resistance Profile of Salmonella Typhimurium to Antimicrobials Commonly Used in Poultry

\section{STATISTICAL ANALYSIS}

All results were statistically tested by Fisher exact test at 5\% significance level.

\section{RESULTS}

\section{Disk diffusion test and Minimum Inhibitory Concentration (MIC)}

There was resistance to all three antibiotics tested (18.1\% ceftiofur, $45.4 \%$ gentamicin, and $18.1 \%$ enrofloxacin) according to the disk diffusion test. However, the isolates of $S$. Typhimurium showed higher levels of resistance: ceftiofur $(27.2 \%)$, gentamicin $(54.5 \%)$, and enrofloxacin (18.2\%) in the MIC test. All susceptibility results for both methodologies tested are described on Table 2.

Table 2 - S. Typhimurium phenotypic profiles determined by disk diffusion tests and MIC to antimicrobials commonly used in poultry.

\begin{tabular}{l|cc|cc}
\hline \multirow{2}{*}{} & \multicolumn{2}{|c|}{ Disk diffusion test } & \multicolumn{2}{c}{ MIC } \\
\cline { 2 - 5 } & $\mathrm{S}(\%)$ & $\mathrm{R}(\%)$ & $\mathrm{S}(\%)$ & $\mathrm{R}(\%)$ \\
\hline Ceftiofur & $9(81,8)$ & $2(18,1)$ & $8(72,7)$ & $3(27,2)$ \\
\hline Gentamicin & $6(54,5)$ & $5(45,4)$ & $5(45,4)$ & $6(54,5)$ \\
\hline Enrofloxacin & $9(81,8)$ & $2(18,1)$ & $9(81,8)$ & $2(18,2)$ \\
\hline
\end{tabular}

S - Sensitive, R - Resistant

Statistical analyses using Fisher exact test for enrofloxacin and ceftiofur showed that the presence or absence of a resistance gene does not interfere with the phenotypic response, meaning that phenotype and genotype are independent variables. On the other hand, gentamicin results analyzed also by Fischer exact test demonstrated dependence between phenotype and genotype.

Table 1 - Resistance genes to each antibiotic tested, specific primer sequence, gene size and references used.

\begin{tabular}{|c|c|c|c|}
\hline Resistance genes & Primers & Size $(p b)$ & Reference \\
\hline GyrA & 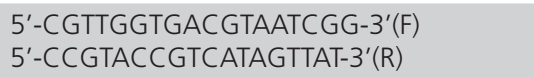 & 251 & Randall et al. (2005) \\
\hline GyrB & 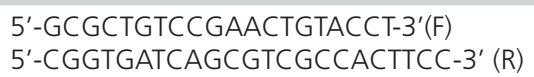 & 181 & Eaves et al. (2004) \\
\hline ParC & $\begin{array}{l}\text { 5'-CTATGCGATGTCAGAGCTGG-3'(F) } \\
\text { 5'-TAACAGCAGCTCGGCGTATT-3'(R) }\end{array}$ & 260 & Randall et al. (2005) \\
\hline ParE & $\begin{array}{l}\text { 5'-TCTCTTCCGATGAAGTGCTG-3'(F) } \\
\text { 5'-ATACGGTATAGCGGCGGTAG-3'(R) }\end{array}$ & 237 & Randall et al. (2005) \\
\hline AadA & $\begin{array}{l}\text { 5'- GTGGATGGCGGCCTGAAGCC-3'(F) } \\
5^{\prime}-\text { ATTGCCCAGTCGGCAGCG-3'(R) }\end{array}$ & 526 & Ribeiro et al. (2011) \\
\hline AadB & $\begin{array}{l}\text { 5'- TCCAGAACCTTGACCGAAC-3'(F) } \\
5^{\prime}-\text { GCAAGACCTCAACCTTTTCC-3'(R) }\end{array}$ & 700 & Ribeiro et al. (2011) \\
\hline BlaCMY-2 & $\begin{array}{l}\text { 5'-TGGCC GAACTGACAGGCAAA-3'(F) } \\
5^{\prime}-\text { TTTCTCCTGAACGTGGCTGGC-3'(R) }\end{array}$ & 354 & Alcaine et al. (2005) \\
\hline AmpC & $\begin{array}{l}\text { 5'-AACACACTGATTGCGTCTGAC-3'(F) } \\
\text { 5'-CTGGGCCTCATCGTCAGTTA-3'(R) }\end{array}$ & 1226 & Alcaine et al. (2005); Pérez-Pérez \& Hanson (2002) \\
\hline
\end{tabular}




\section{PCR}

All enrofloxaxin-sensitive ST strains showed at least three out of the four search genes. We were unable to find $A a d A$ and $A a d B$ gentamicin genes in two resistant ST strains. On the other hand, as expected, all gentamicin-sensitive strains lacked both genes. Resistance genes for ceftiofur (AmpC and BlaCMY) were found in samples presenting both resistant and sensitive phenotypic profile. All results obtained from the genotypic isolates of $S$. Typhimurium are shown in Table 3.

\section{DISCUSSION}

The emergence of antimicrobial resistance in zoonotic bacteria has important implications for public health. Data from several researchers suggest that the indiscriminate use of antimicrobials can lead to resistance of several bacteria that, which can reach consumers through products of animal origin (Ribeiro et al., 2011).

A third-generation cephalosporin is used to treat animals infected with Salmonella sp as well as humans, especially children (Frye \& Cray, 2007). These authors reported a growing global concern due to the emergence of multidrug-resistant strains, and isolates of S. Typhimurium accounted for $23.5 \%$ of the observed resistance to ceftiofur with values very close to those found in this study.

The genetic element responsible for most of the resistance to ceftiofur in Salmonella sp isolated from animals in the USA seems to be related to the BlaCMY gene (Frye \& Cray, 2007). This was also reported by
Alcaine et al. (2005), who observed that nineteen resistant Salmonella isolates carried the ceftiofur gene BlaCMY. Studies conducted by Frye \& Cray (2007) reported that $17 \%$ of resistant strains did not have the BlaCMY gene or some other $\beta$-lactamase resistant genes detected by $P C R$, raising a concern that other mechanisms are associated to ceftiofur resistance. Our results, however, showed that all ceftiofur resistant strains carried at least one of the resistant genes.

Studies by Peirano et al. (2006) in Brazil showed that the number of Salmonella sp isolates resistant to ceftiofur was $16.3 \%$, out of which only $13.6 \%$ had the BlaCMY gene, indicating that some other genes that may also be responsible for resistance.

ST samples with a sensitive phenotype and the presence of a resistance gene may be explained by the study of Alberts (2004), who suggested the possibility that the gene may not be expressed at the time of the analysis.

Our results for gentamicin resistance in disk diffusion test (45.4\%) and in MIC (54.5\%) differ from those found by Medeiros (2006), who worked mainly with animal and food samples (12.4\%). It was not possible to detect a resistance gene in one ST sample with resistant phenotype for gentamicin. Ribeiro et al. (2011) and Peirano et al. (2006) also reported that it was not always possible to correlate phenotype and genotype. The absence of the gene in isolates showing phenotypic resistance suggested that there are other mechanisms related to resistance, warranting further research.

ST samples showed $18 \%$ resistance to enrofloxacin, confirming multidrug resistance to all three antibiotics

Table 3 - Presence of antimicrobial resistance genes to enrofloxacin, ceftiofur, and gentamicin in S. Typhimurium isolates.

\begin{tabular}{|c|c|c|c|c|c|c|c|c|c|c|c|c|c|c|}
\hline \multirow[b]{2}{*}{ Source/State } & \multicolumn{6}{|c|}{ ENROFLOXACIN } & \multicolumn{4}{|c|}{ GENTAMICIN } & \multicolumn{4}{|c|}{ CEFTIOFUR } \\
\hline & MIC & ATB & $\begin{array}{l}\text { Gene } \\
\text { ParC }\end{array}$ & $\begin{array}{l}\text { Gene } \\
\text { ParE }\end{array}$ & $\begin{array}{l}\text { Gene } \\
\text { GyrA }\end{array}$ & $\begin{array}{l}\text { Gene } \\
\text { GyrB }\end{array}$ & MIC & ATB & $\begin{array}{l}\text { Gene } \\
\text { AadA }\end{array}$ & $\begin{array}{l}\text { Gene } \\
\text { AadB }\end{array}$ & $\mathrm{MIC}$ & ATB & $\begin{array}{l}\text { Gene } \\
\text { AmpC }\end{array}$ & $\begin{array}{c}\text { Gene } \\
\text { BlaCMY }\end{array}$ \\
\hline $\mathrm{FB} / \mathrm{SC}$ & $S$ & $S$ & $P$ & $P$ & $P$ & $P$ & $S$ & $S$ & $\mathrm{~N}$ & N & $S$ & $S$ & $P$ & N \\
\hline SA/PR & S & S & $P$ & $P$ & $P$ & $P$ & $\mathrm{R}$ & $\mathrm{R}$ & N & $P$ & $\mathrm{R}$ & $\mathrm{R}$ & $P$ & $\mathrm{~N}$ \\
\hline SA/PR & S & S & P & $P$ & $P$ & $P$ & $\mathrm{R}$ & $\mathrm{R}$ & $\mathrm{N}$ & $\mathrm{N}$ & $\mathrm{S}$ & $\mathrm{S}$ & $\mathrm{N}$ & $\mathrm{N}$ \\
\hline SA/PR & $S$ & $S$ & $P$ & $N$ & $P$ & $P$ & $\mathrm{R}$ & R & $P$ & $N$ & $S$ & $S$ & N & $\mathrm{N}$ \\
\hline SA/PR & $S$ & $S$ & $P$ & $P$ & $P$ & $P$ & $R$ & $\mathrm{R}$ & P & $\mathrm{N}$ & S & S & $\mathrm{N}$ & P \\
\hline SA/PR & S & S & $P$ & $P$ & $P$ & $P$ & S & S & N & $\mathrm{N}$ & S & S & N & $P$ \\
\hline SA/PR & $S$ & $S$ & N & $P$ & $P$ & $P$ & $S$ & $S$ & N & N & $S$ & $S$ & $P$ & N \\
\hline SA/PR & $S$ & $S$ & $P$ & $P$ & $P$ & $P$ & $\mathrm{R}$ & $\mathrm{R}$ & $P$ & $N$ & $R$ & $\mathrm{R}$ & $P$ & $N$ \\
\hline SC/PR & $R$ & $R$ & $P$ & $P$ & $P$ & $P$ & $S$ & $S$ & N & N & $R$ & $S$ & $P$ & $P$ \\
\hline SA/SC & $S$ & $S$ & $P$ & $P$ & $N$ & $P$ & $\mathrm{R}$ & S & $N$ & $N$ & S & S & $P$ & $N$ \\
\hline SA/PR & $\mathrm{R}$ & $\mathrm{R}$ & $P$ & $P$ & $P$ & $P$ & S & S & $\mathrm{N}$ & $\mathrm{N}$ & S & $\mathrm{s}$ & $\mathrm{N}$ & $\mathrm{N}$ \\
\hline
\end{tabular}

FB - feed for breeders, SA - drag-swab, SC - cloacal swab; SC - Santa Catarina, PR - Paraná; S - Sensitive R - Resistant; P - gene present; N - No gene 
tested in most of the samples. Interestingly, all samples presented resistance genes to enrofloxacin, independently of their phenotype, showing their genetic potential to become resistant in the future.

Borsoi et al. (2005) and Ribeiro et al. (2011) found high resistance values for enrofloxacin $(69.2 \%$ and $15 \%$, respectively) in Salmonella sp samples. It appears that mutations in the GyrA gene may be responsible for the resistance to fluoroquinolones. In contrast, San Martin et al. (2005), evaluating 39 samples of Salmonella sp, found no resistance to enrofloxacin. According to these authors, phenotypic resistance to this antibiotic only occurs when there are doublesingle point mutations in the GyrA gene, which may explain why the isolates evaluated in the present study presented the GyrA gene, but did not express it phenotypically.

\section{CONCLUSIONS}

Our study showed that tested ST isolates were resistant to three antibiotics evaluated; however, the most significant resistance was observed relative to ceftiofur and gentamicin. The use of molecular tests is important because it shows the future antimicrobial resistance profile. In this study, we observed that most isolates presented the genes of resistance, although these were not being expressed yet, demonstrating the future potential for these strains to become resistant to the evaluated antimicrobial agents.

\section{ACKNOWLEDGEMENTS}

We would like to thank FIOCRUZ (Osvaldo Cruz Foundation), CEDIMA (Animal Microbiological Diagnostic Center - (AV/UDESC), Mercolab Laboratories, and Laboratory for Hemoparasites and Vectors (CAV/UDESC).

\section{REFERENCES}

Alberts B. Controle da Expressão Gênica. In: Alberts, B, Johnson A, Lewis J, Raff, M, Roberts, K, Walter, P. Artmed. Biologia Molecular da Célula. Porto Alegre; 2004. p. 375-466.

Alcaine SD, Sukhnanand SS, Warnick LD, Su WL, Mcgann P, Mcdonough P, Wiedmann M. Ceftiofur-Resistant Salmonella Strains Isolated from Dairy Farms Represent Multiple Widely Distributed Subtypes That Evolved by Independent Horizontal Gene Transfer. Antimicrobial Agents and Chemotherapy 2005; 49(10): 4061-4067.

Borsoi A, Santin E, Santos ER, Salle CTP, Moraes HLS, Nascimento VP. Inoculation of newly hatched broiler chicks with two Brazilian isolates of Salmonella Heidelberg strains with different virulence gene profile, antimicrobial resistance and pulsed field gel electrophoresis pattern to intestinal changes evaluation. Poultry Science 2009; 88:750-758.
Brasil. Agência Nacional de Vigilância Sanitária (ANVISA). Padronização dos Testes de Sensibilidade a Antimicrobianos por Disco-difusão: Norma Aprovada 8 ed. 23(1); 2003.

Carrasco E, Morales-Rueda A, Garcia-Gimeno RM. Cross-contamination and recontamination by Salmonella in foods: A review. Food Research International 2012; 45:545-556.

Eaves DJ, Randall L, Gray DT, Woodward MJ, White AP, Buckley A, Piddock LJV. Prevalence of Mutations within the Quinolone ResistanceDetermining Region of GyrA, GyrB, ParC, and ParE and Association with Antibiotic Resistance in Quinolone-Resistant Salmonella enterica. Antimicrobial Agents and Chemotherapy 2004; 48(10):4012-4015.

Frye JG, Fedorka-Cray PJ. Prevalence, distribuition and characterization of Ceftiofur resistance in Salmonella enterica isolated from animals in the USA from 1999 to 2003. Antimicrobial Agents and Chemotherapy 2007; 30:134-142.

Guerra B, Soto SM, Cal S, Mendoza MC. Antimicrobial Resistance and Spread of Class 1 Integrons among Salmonella Serotypes. Antimicrobial Agents and Chemotherapy 2000; 44(8):2166-2169.

Medeiros ML. Estudo sobre cepas de Salmonella enterica sorovar Typhimurium resistentes a antimicrobianos isoladas de diferentes fontes da cadeia alimentar no Brasil. [Dissertation]. Rio de Janeiro (RJ): Fundação Oswaldo Cruz; 2006

Peirano G, Agersø Y, Aarestrup F, Dos Reis EMF, Dos Prazeres RD. Occurrence of integrons and antimicrobial resistance genes among Salmonella enterica from Brazil. The Journal of Antimicrobial Chemotherapy 2006; 58(2):305-309.

Pérez-Pérez FJ, Hanson ND. Detection of Plasmid-Mediated AmpC Lactamase Genes in Clinical Isolates by Using Multiplex PCR. Journal of Clinical Microbiology 2002; 40(6):2153-2162.

Randall LP, Coldham NG, Woodward MJ. Detection of mutations in Salmonella enterica GyrA, GyrB, ParC and ParE genes by denaturing high performance liquid chromatography (DHPLC) using standard HPLC instrumentation. Journal of Antimicrobial Chemotherapy 2005; 56:619-623

Ribeiro VB, Lincopan N, Landgraf M, Franco BDGM, Destro MT. Characterization of class 1 integrons and antibiotic resistance genes in multidrug resistant Salmonella enterica isolates from foodstuff and related sources. Brazilian Journal of Microbiology 2011; 42:685-692.

San Martin B, Lapierre R, Toro C, Bravo V, Cornejo J, Hormazabal JC, Borie C. Isolation and molecular characterization of quinolone resistant Salmonella spp. from poultry farms. Veterinary Microbiology 2005; 110:239-244 